\title{
ANALISIS PERENCANAAN PEMBANGUNAN DAN PENINGKATAN KUALITAS INFRASTRUKTUR EKONOMI SOSIAL UNTUK MENINGKATKAN KUALITAS PENDIDIKAN
}

\section{Siti Zulekha, Muhsin}

Jurusan Pendidikan Ekonomi, Fakultas Ekonomi, Universitas Negeri Semarang, Indonesia

\begin{tabular}{|c|c|}
\hline Info Artikel & Abstrak \\
\hline $\begin{array}{l}\text { Sejarah Artikel: } \\
\text { Diterima,2 Februari } 2020 \\
\text { Disetujui, } 13 \text { Maret } 2020 \\
\text { Dipublikasikan,30 Juni } 2020\end{array}$ & $\begin{array}{l}\text { Pembangunan dan peningkatan kualitas infrastruktur ekonomi sosial di Kabupaten Batang dilakukan } \\
\text { sebagai salah satu upaya mewujudkan kualitas bidang pendidikan. Penelitian ini bertujuan untuk } \\
\text { mendeskripsikan dan menganalisis proses perencanaan dan pencapaian pembangunan infrastruktur di } \\
\text { Kabupaten Batang dengan pendekatan deskriptif kualitatif. Teknik pengumpulan data dengan } \\
\text { wawancara dan dokumentasi. Teknik pemerikasaan keabsahan data dilakukan dengan triangulasi sumber. } \\
\text { Teknik analisis data dilakukan secara deskriptif kualitatif. Hasil penelitian menemukan bahwa (1) Proses } \\
\text { perencanaan pembangunan dan peningkatan kualitas infrastruktur ekonomi sosial untuk meningkatkan }\end{array}$ \\
\hline $\begin{array}{l}\text { Keywords: } \\
\text { Development Planning, } \\
\text { Infrastructure, Economy, } \\
\text { Social and Education } \\
\text { Quality }\end{array}$ & $\begin{array}{l}\text { kualitas pendidikan di Kabupaten Batang menjadi tugas dan kewenangan dari Bappelitbang Kabupaten } \\
\text { Batang melalui empat proses yaitu penyusunan rancangan awal, pelaksanaan Musrenbang, perumusan } \\
\text { rancangan akhir; dan penetapan rencana. (2) Hasil pembangunan dan peningkatan kualitas infrastruktur } \\
\text { ekonomi sosial di Kabupaten Batang pada tahun } 2018 \text { adalah sebesar } 75,77 \% \text { atau pencapaiannya cukup } \\
\text { berhasil/cukup baik. Capaian pada indikator pendidikan jenjang PAUD mengalami peningkatan dari } \\
\text { tahun } 2012 \text { sampai } 2016 \text { sehingga dapat dikategorikan baik. Pada jenjang sekolah dasar } 9 \text { tahun } \\
\text { mengalami fluktuasi pada tiap indikator. Pada indikator angka kelulusan untuk SD/MI perlu ditingkatkan } \\
\text { kembali. Capaian pada jenjang SMA/SMK pada tiap indikator mengalami fluktuasi, sementara angka } \\
\text { kelulusan pada jenjang SMA/SMK/MA ini perlu untuk tingkatkan kembali. }\end{array}$ \\
\hline
\end{tabular}

\section{Abstract}

The development and improvement of the quality of social economic infrastructure in Batang Regency as an effort to realize the quality of the education sector. This study aims to describe and analyze the palnning process and achievement of infrastucture development in Batang with a descriptive qualitative approach. Data collection techniques with interview, and documentation. The technique for checking the validity of data is triangulation of source. The data anaysis technique was done in a descriptive qualitative manner. The results of the study found that (1) The process of development planning and improvement of the quality of social economic infrastructure to improve the quality of education in Batang District became the task and authority of the Bappelitbang of Batang Regency through four processes, namely the preparation of the initial design, the implementation of the Musrenbang, and the formulation of the final design; and establishing plans. (2) The results of the development and improvement of the quality of social economic infrastructure in Batang Regency in 2018 amounted to $75.77 \%$ or the achievements were quite successful / quite good. Achievements on early childhood education indicators have increased from 2012 to 2016 so that they can be categorized well. At the elementary school level 9 years experienced fluctuations in each indicator. The graduation rate indicator for basic schools needs to be increased again. Achievements at the high school level on each indicator have fluctuated, while the graduation rate at the high schools level needs to be improved again.

(C) 2020 Universitas Negeri Semarang

Alamat korespondensi:

Gedung L2 Lantai 1 FE Unnes

Kampus Sekaran, Gunungpati, Semarang, 50229

E-mail: izulszulekhah@gmail.com 


\section{PENDAHULUAN}

Pembangunan merupakan upaya secara sadar untuk mengelola dan memanfaatkan sumber daya yang tersedia untuk dapat meningkatkan mutu kehidupan masyarakat termasuk pendidikan. Upaya pembangunan daerah akan dimanfaatkan aspek-aspek yang secara ekonomi berpotensi untuk dikembangkan. Potensi ekonomi dalam kerangka pembangunan daerah dapat diartikan sebagai kesanggupan, kekuatan, dan kemampuan di bidang ekonomi yang dimiliki oleh suatu daerah untuk membangun daerah tersebut. Proses pembangunan tidak terjadi begitu saja, tetapi harus diciptakan melalui intervensi pemerintah, melalui kebijakankebijakan yang mendorong terciptanya proses pembangunan.

Peranan pemerintah dalam pembangunan daerah adalah (a), entrepreneur, yaitu pemerintah daerah bertanggung jawab untuk merangsang jalannya suatu usaha bisnis; (b), koordinator, yaitu pemerintah daerah sebagai koordinator dalam penetapan suatu kebijakan atau strategi-strategi bagi pembangunan daerah; (c), fasilitator, yaitu pemerintah daerah dapat mempercepat pembangunan melalui perbaikan lingkungan attitudional di daerahnya; (d), stimulator, yaitu pemerintah daerah dapat menstimulasi penciptaan dan pengembangan usaha melalui tindakan-tindakan khusus yang akan mempengaruhi investor baru agar masuk dan mempertahankan serta menumbuhkembangkan investor yang telah ada di daerahnya (Purwansyah, 2013:30).

Pemerintah daerah sebagai fasilitator dalam proses pembangunan daerah yaitu salah satunya terkait dengan percepatan pembangunan dan peningkatan kualitas infrastruktur ekonomi dan sosial. Dalam meningkatkan perkembangan sosial dan kegiatan ekonomi wilayah, prasarana (infrastruktur) umum merupakan hal yang penting. Pembangunan tidak dapat berjalan dengan lancar jika prasarana tidak baik. Setiap aspek kehidupan sosial maupun ekonomi mempunyai prasarana sendiri, yang merupakan satuan terbesar dan alat utama dalam berbagai kegiatan. Oleh karena itu, dalam mengsukseskan pembangunan setiap daerah harus memperhatikan infrastrukturnya (Posumah, 2015:2).

Infrastruktur pendidikan juga merupakan hal yang perlu diperhatikan. Sarana dan prasarana untuk meningkatkan kualitas pendidikan perlu terus ditingkatkan dan dikembangkan. Hal tersebut bertujuan untuk mendukung proses pembelajaran agar dapat lebih efektif dan efisien. Infrastruktur baik dari gedung, ruang kelas, maupun perpustakaan, sarana dan prasarana lainnya menjadi pendukung dalam proses pembelajaran dalam tiap jenjang sekolah.

Berdasarkan hasil kajian dan laporan terbaru Badan Perencanaan Pembangunan Nasional (Bappenas), Bank Pembangunan Asia (ADB) dan Organisasi Buruh Internasional (ILO) bertajuk "Indonesia Critical Constraints", ketersediaan dan kualitas infrastruktur menjadi salah satu dari tiga masalah yang harus segera dibenahi pemerintah. Perbaikan dan pembangunan akses terhadap pelayanan infrastruktur dasar adalah salah satu harapan yang berhak diperoleh masyarakat dan wajib diselenggarakan oleh pemerintah (Hidayat dan Mulyadi, 2018:2).

Kemampuan perekonomian daerah terkait dengan permasalahan belum meratanya ketersediaan infrastuktur khususnya infrastruktur ekonomi sosial menjadi perhatian penting bagi seluruh pihak. Hal ini dikarenakan keberhasilan ekonomi dan kualitas sosial masyarakat dinilai mampu mendukung upaya penanggulangan kemiskinan. Infrastruktur ekonomi berupa pembangunan sarana prasarana fisik maupun peningkatan kualitas sarana prasarana fisik mampu mempengaruhi secara dominan terhadap pertumbuhan ekonomi suatu daerah. Kemampuan ekonomi yang kurang akan mempengaruhi kemampuan masyarakat untuk menyekolahkan anak. Hal ini akan berpengaruh terhadap kualitas pendidikan daerah tersebut.

Pemerintah Kabupaten Batang dalam rangka mengurangi jumlah anak putus sekolah dan meningkatkan mutu pelayanan pendidikan menempuh kebijakan Pembebasan Biaya Pendidikan Dasar (SD dan SMP) se-Kabupaten 
Batang. Untuk peningkatan dan pemenuhan kebutuhan sarana dan prasarana pendidikan telah dilakukan upaya peningkatan sarana dan prasarana pendidikan dasar SD sejumlah 21 sekolah, SMP sejumlah 9 sekolah, rehabilitasi sedang atau berat bangunan sekolah SD sejumlah 4 sekolah, pembangunan perpustakaan sekolah SD sejumlah 39 sekolah, penambahan ruang kelas SD sejumlah 1 sekolah, SMP sejumlah 4 sekolah, pembangunan laboratorium dan ruang praktikum 4 sekolah, rehabilitasi sedang atau berat ruang kelas 204 ruang, SMP sejumlah 22 sekolah, pembangunan ruang kelas SMP sejumlah 14 ruang.

Pembangunan dan peningkatan kualitas infrastruktur di Kabupaten Batang tersebut sebagai upaya mewujudkan misi pembangunan Kabupaten Batang Tahun 2017 - 2022 untuk bidang infrastruktur yaitu "meningkatkan pengembangan perekonomian daerah secara berkelanjutan didukung infrastruktur dan kawasan berkualitas yang ramah lingkungan dengan tetap menerapkan prinsip-prinsip pembangunan berkelanjutan".

Pemerintah Kabupaten Batang terus meningkatkan pembangunan infrastruktur ekonomi sosial dan pendidikan. Capaian Rasio Ketersediaan Sekolah per Penduduk pada jenjang pendidikan dasar cenderung mengalami peningkatan dari tahun 2012 sebesar 60,21 menjadi 64,37 pada tahun 2016 begitu juga dengan Rasio Ketersediaan Sekolah per Penduduk pada jenjang pendidikan menengah cenderung mengalami peningkatan dari tahun 2012 sebesar 11,64 menjadi 13,54 pada tahun 2016.

Sementara itu capaian indikator Sekolah Pendidikan SD/MI kondisi bangunan baik mengalami fluktuasi dan cenderung menurun dari tahun 2012 sebesar 99,4 menjadi 95,54 pada tahun 2016, begitu juga Sekolah Pendidikan SMP/MTs dan SMA/SMK/MA kondisi bangunan baik cenderung mengalami penurunan dari tahun 2012 sebesar 95,21 menjadi 94,11 pada tahun 2016 .

Penelitian ini bertujuan untuk mendeskripsikan dan menganalisis proses perencanaan dan pencapaian pembangunan infrastruktur di Kabupaten Batang.

\section{KAJIAN PUSTAKA}

Penyelenggaraan pemerintahan daerah diarahkan untuk mempercepat terwujudnya kesejahteraan masyarakat melalui peningkatan pelayanan, pemberdayaan, dan peran serta masyarakat, serta peningkatan daya saing daerah dengan memperhatikan prinsip demokrasi, pemerataan, keadilan, dan kekhasan suatu daerah dalam sistem Negara Kesatuan Republik Indonesia. Kemudian Pasal 18 ayat (2) dan ayat (5) Undang-Undang Dasar Negara Republik Indonesia Tahun 1945 menyatakan bahwa "Pemerintahan Daerah berwenang untuk mengatur dan mengurus sendiri urusan pemerintahan menurut asas otonomi dan tugas pembantuan dan diberikan otonomi yang seluas-luasnya".

\begin{tabular}{lrr}
\multicolumn{2}{c}{ Pembangunan daerah } & merupakan \\
pembangungan yang segala & sesuatunya \\
dipersiapkan dan dilaksanakan & oleh darerah, \\
mulai dari perencanaan, & pembiayaan, \\
pelaksanaan & sampai & dengan
\end{tabular}
pertanggungjawabannya. Dalam kaitan ini daerah memiliki hak otonom. Sedangkan pembangunan wilayah merupakan kegiatan pembangunan yang perencanaan, pembiayaan, dan pertanggungjawabannya dilakukan oleh pusat, sedangkan pelaksanaannya bisa melibatkan daerah di mana tempat kegiatan tersebut berlangsung (Munir, 2002).

Pasal 150 Undang-Undang Nomor 32 tahun 2004 ayat (3) disebutkan bahwa, perencanaan pembangunan daerah disusun secara berjangka yang meliputi: Rencana Pembangunan Jangka Panjang Daerah, disingkat RPJP Daerah untuk jangka waktu 20 tahun yang memuat visi, misi dan arah pembangunan daerah yang mengacu kepada RPJP Nasional.

Rencana Pembangunan Jangka Menengah Daerah selanjutnya disebut RPJM Daerah untuk jangka waktu 5 tahun. RPJM Daerah merupakan penjabaran dari visi, misi dan program kepala daerah yang penyusunannya berpedoman kepada RPJP Daerah dengan memperhatikan RPJM Nasional. RPJM Daerah memuat arah kebijakan keuangan daerah, strategi pembangunan daerah, kebijakan umum dan 
program satuan kerja perangkat daerah, lintas satuan kerja perangkat daerah dan program kewilayahan disertai dengan rencana kerja dalam kerangka regulasi dan kerangka pendanaan yang bersifat indikatif.

Rencana Kerja Pemerintah Daerah (RKPD), merupakan penjabaran dari RPJM Daerah untuk jangka waktu 1 (satu) tahun, yang memuat rancangan kerangka ekonomi daerah, prioritas pembangunan daerah, rencana kerja dan pendanaannya, baik yang dilaksanakan langsung oleh pemerintah daerah maupun ditempuh dengan mendorong partisipasi masyarakat, dengan mengacu kepada rencana kerja pemerintah.

Infrastruktur dapat diartikan sebagai sarana dan prasarana umum. Sarana secara umum diketahui sabagai fasilitas publik seperti rumah sakit, jalan, jembatan, sanitasi, telpon. Lebih jauh lagi, dalam ilmu ekonomi infrastruktur merupakan wujud dari public capital (modal publik) yang dibentuk dari investasi yang dilakukan pemerintah. Infrastruktur meliputi jalan, jembatan, dan sistem saluran pembuangan (Mankiw, 2003: 38). Familoni (2004: 16) menyebut infrastruktur sebagai basic essential service dalam proses pembangunan.

Menurut Familoni (2004: 20) secara umum, infrastruktur berdasarkan fungsi dan peruntukannya dapat dibedakan menjadi infrastruktur ekonomi dan sosial. Infrastruktur ekonomi memegang peranan penting dalam mendorong kinerja pertumbuhan ekonomi di berbagai negara. Infrastruktur ekonomi diantaranya utilitas publik seperti tenaga listrik, telekominukasi, suplai air bersih, sanitasi dan saluran pembuangan serta gas. Kemudian termasuk pula pekerjaan umum, seperti jalan, kanal, bendungan, irigasi dan drainase serta proyek transportasi seperti jalan kereta api, angkutan kota, dan bandara. Sedangkan infrastruktur sosial dapat dibedakan menjadi infrastruktur pendidikan dan kesehatan.

Kualitas yang baik merupakan dambaan setiap orang, terlebih dalam bidang pendidikan. Kualitas pendidikan biasanya terdiri dari beberapa indikator dan komponen yang saling barkait. Komponen dan variabel yang menetukan terwujudnya mutu pendidikan yang baik secara umum, masih dikaitkan dengan sistem, kurikulum, tenaga pendidik, peserta didik, PBM, anggaran, sarana dan prasarana pendidikan, lingkungan belajar, budaya organisasi, kepemimpinan dan lain sebagainya (Onisimus, 2010). Dalam konteks pendidikan, kualitas dapat diartikan sebagai kemampuan sekolah dalam pengelolaan secara operasional dan efisien terhadap komponen-komponen yang berkaitan dengan sekolah, sehingga menghasilkan nilai tambah terhadap komponen tersebut menurut standar yang berlaku.

Pendidikan dalam rumusan nasional Undang-Undang Republik Indonesia No. 20 Tahun 2003, Bab I, Pasal 1 adalah Pendidikan adalah usaha sadar dan terencana untuk mewujudkan suasana belajar dan proses pembelajaran agar peserta didik secara aktif mengembangkan potensi dirinya untuk memiliki kekuatan spiritual keagamaan, pengendalian diri, kepribadian, kecerdasan, akhlak mulia, serta keterampilan yang diperlukan dirinya, masyarakat, bangsa dan negara.

Pendidikan yang berkualitas harus menjadi tujuan utama. Dalam rangka mewujudkan, menjaga, dan terus meningkatkan kualitas atau mutu pendidikan, maka dalam penyelenggaraan pendidikan atau penyelenggaraan proses pembelajaran perlu diadopsi manajemen mutu.

Manajemen mutu dalam pendidikan yang sering disebut sebagai Total Quality Education (TQE). Aplikasi konsep manajemen mutu-TQM dalam pendidikan ditegaskan oleh Sallis (2012:73) yaitu Total Quality Management adalah sebuah filosofi tentang perbaikan secara terus-menerus, yang dapat memberikan seperangkat alat praktis kepada setiap institusi pendidikan dalam memenuhi kebutuhan, keinginan, dan harapan para pelangganya, saat ini dan untuk masa yang akan datang.

Pendidikan yang berkualitas telah memasuki babak baru dalam dunia pendidikan. Tak satu pun lembaga penyelenggara pendidikan yang luput dari tuntutan ini. Tuntutan tersebut tidak pandang pilih, baik tingkatannya maupun orang-orangnya, apakah itu di tingkat pendidikan dasar atau pun di tingkat perguruan tinggi; apakah bertindak 
sebagai kepala sekolah, atau sebagai dosen, guru, karyawan, maupun peserta didik. Semua dituntut secara bersama-sama dalam menciptakan pendidikan yang berkualitas. Tentunya tuntutan tersebut disesuaikan dengan tugas dan perannya masing-masing, serta berdasarkan standar atau ukuran kualitas yang telah ditetapkan. Salah satu pertanda bahwa pendidikan tersebut berkualitas adalah terlaksananya sistem pembelajaran secara baik, yang secara menyeluruh melibatkan semua komponen-komponen yang ada dalam sistem pembelajaran.

Menurut Sallis (2012:58) mutu atau kualitas dapat dipandang sebagi sebuah konsep yang absulut dan relatif. Kualitas dalam konsep layanan didefinisikan sebagai sesuatu yang memuaskan dan melampaui keinginan dan kebutuhan pelanggan. Kualitas dalam konteks ini dianggap sebagai mutu sesuai persepsi (quality in perception), di mana sesuatu dikatakan bermutu hanya dapat didefinisikan sendiri dari orang yang melihat atau merasakannya yaitu pelanggan. Jadi dapat diartikan bahwa, konsep layanan pendidikan yang dimaksudkan adalah layanan yang diberikan kepada pelanggan pendidikan secara memuaskan dan dapat memenuhi kebutuhannya dalam hal pendidikan.

Sistem jaminan kualitas pendidikan harus berisi elemen-elemen yaitu pengembangan institusi, rencana strategis, kebijakan kualitas, tanggung jawab manajemen, pengorganisasian kualitas, pemasaran dan publisitas, penyelidikan dan pendaftaran, pelahiran kurikulum, bimbingan dan konseling, manajemen pembelajaran, desain kurikulum, staffing, training dan pengembangan, kesempatan yang seimbang, monitoring dan evaluasi, perancangan administrasi dan review organisasi (Sallis, 2012:131).

\section{METODE PENELITIAN}

Penelitian ini adalah kualitatif. Sumber data penelitian ini meliputi sumber data primer dan data sekunder. Teknik pengumpulan data yang digunakan wawancara dan dokumentasi. Pengujian validitas data dalam penelitian ini dilakukan dengan triangulasi sumber dan triangulasi metode. Analisis data dalam penelitian ini dilakukan secara deskriptif kualitatif yang terdiri dari tiga aktivitas yaitu: reduksi data, penyajian data, dan verifikasi.

\section{HASIL DAN PEMBAHASAN}

Kabupaten Batang terletak antara 6051' 46" dan 7011' 47" Lintang Selatan dan antara 109040' 19" dan 110003' 06" Bujur Timur. Letak Kabupaten Batang berada pada pesisir pantai utara Pulau Jawa. Wilayah administrasi Kabupaten Batang pada tahun 2018 terdiri dari 15 kecamatan, 248 desa dan kelurahan, 934 dusun, 3.680 Rukun Tetangga (RT) dan 1.009 Rukun Warga (RW).

Sejak berdirinya, Kabupaten Batang telah terjadi perkembangan yang cukup signifikan dalam bidang pemerintahan, dimana pada awalnya terdiri dari 12 (dua belas) kecamatan. Pada tahun 2007 dimekarkan menjadi 15 kecamatan. Berdasarkan Peraturan Daerah Kabupaten Batang Nomor 7 Tahun 2004 tentang Pembentukan Kecamatan Kabupaten Batang, jumlah kecamatan di Kabupaten Batang yang semula 12 kecamatan berubah menjadi 15 kecamatan.

Perencanaan pembangunan daerah termasuk dalam pembangunan infrastruktur ekonomi dan sosial di Kabupaten Batang menjadi tugas dan kewenangan Bappelitbang Kabupaten Batang untuk mewujudkan pembangunan daerah sesuai dengan rencana strategis yang telah ditetapkan. Penyusunan kebijakan atau perencanaan pembangunan infrastruktur ekonomi dan sosial di Kabupaten Batang berada pada Bidang Infrastruktur dan Pengembangan Wilayah. Bidang ini bertugas menyusun, mengkoordinasikan, mengatur, memantau dan mengevaluasi serta melaporkan kegiatan perencanaan pembangunan daerah bidang infrastruktur dan pengembangan wilayah.

Hasil penelitian menemukan bahwa proses perencanaan pembangunan infrastruktur ekonomi dan sosial di Kabupaten Batang oleh Bappelitbang Kabupaten Batang meliputi 4 tahapan yaitu penyusunan rancangan awal, pelaksanaan Musrenbang, perumusan rancangan akhir; dan penetapan rencana. Namun proses yang menunjukkan adanya partisipatif yaitu pada proses pelaksanaan 
Musrebang yang meliputi Musrenbang Desa atau Kelurahan, Musrenbang Kecamatan, Forum Satuan Kerja Pemerintah Daerah (Forum SKPD) dan Musrenbang Kota.

Proses perencanaan pembangunan daerah melalui penyusunan RPJPD, RPJMD dan RKPD diawali dengan penyusunan rancangan awal yang berisikan kebijakan umum dan program pembangunan daerah dan indikasi program prioritas yang disertai kebutuhan pendanaan, dan sesuai ketentuan untuk dibahas antara Eksekutif dan Legislatif, agar memperoleh kesepakatan yang dituangkan dalam nota kesepakatan. Rancangan awal kemudian ditandatangani oleh Kepala Daerah dan Ketua DPRD sesuai dengan ketentuan Pasal 15 PP Nomor 8 Tahun 2008 dan Pasal 76 Permendagri Nomor 54 Tahun 2010 ditetapkan selambat-lambatnya 6 (enam) bulan setelah Kepala Daerah Terpilih dilantik.

Pembangunan infrastruktur ekonomi sosial di Kabupaten Batang pada dasarnya tidak terlepas dari tujuan peningkatan kualitas pendidikan. Setiap satuan pendidikan wajib memiliki sarana dan prasarana pendidikan yang meliputi tanah atau gedung, sarana prasarana pendidikan, media pendidikan, buku dan sumber belajar lainnya, bahan habis pakai, serta perlengkapan lain yang diperlukan untuk menunjang proses pembelajaran yang teratur dan berkelanjutan.

Standar sumber belajar lainnya untuk setiap satuan pendidikan dinyatakan dalam rasio jumlah sumber belajar terhadap peserta didik sesuai dengan jenis sumber belajar dan karakteristik satuan pendidikan. Ketentuan sarana dan prasarana pendidikan yang wajib dimiliki oleh satuan pendidikan dan rasio sumber belajar terhadap peserta didik diatur menurut standar minimal sarana prasarana pendidikan berdasarkan peraturan perundangundangan. Oleh karena itu, Pemerintah Daerah Kabupaten Batang mengupayakan pemenuhan sarana dan prasarana pendidikan di daerah sesuai dengan kebijakan, kemampuan dan kewenangan daerah. Pemenuhan sarana dan prasarana pendidikan diselenggarakan dalam rangka memenuhi standar minimal pendidikan dan dilaksanakan menurut prioritas, kebutuhan, memadai, merata dan berkelanjutan.

Komposisi penduduk berdasarkan pendidikan dapat dilihat pada tabel 1 berikut:

Tabel 1. Komposisi Jumlah Penduduk Berdasarkan Jenjang Pendidikan Tahun 2016

\begin{tabular}{|c|c|c|}
\hline Jenjang Pendi & ikan & Jumlah \\
\hline Tidak /belum & Tamat & 199.600 \\
\hline SD & & 268.487 \\
\hline SLTP & & 104.866 \\
\hline SLTA & & 57.491 \\
\hline Diploma I/II & & 5.336 \\
\hline Diploma III & & 4.679 \\
\hline Perguruan & & 9.340 \\
\hline \multicolumn{3}{|l|}{ D.IV/S1/S2/S3 } \\
\hline Jumlah & & 649.799 \\
\hline
\end{tabular}

Sumber: RPJMD Kabupaten Batang Tahun 2017-2022

PAUD mempersiapkan anak sejak dini untuk memiliki tumbuh kembang yang baik, emosional dan juga perkembangan psikomotorik yang dapat tarpantau dan terbina. Kinerja sektor pendidikan anak usia dini dapat dilihat dari indikator angka partisipasi pendidikan anak usia dini yang dalam kurun waktu tahun 2012 sampai dengan 2016 cenderung mengalami peningkatan, selengkapnya ditunjukan pada tabel 2 berikut :

Tabel 2. Capaian Indikator Pendidikan Anak Usia Dini Kabupaten Batang 2012-2016

\begin{tabular}{lcccccc}
\hline \multicolumn{1}{c}{ Indikator } & \multirow{2}{*}{ Satuan } & \multicolumn{5}{c}{ Capaian Kinerja Tahun } \\
\cline { 3 - 7 } & & 2012 & 2013 & 2014 & 2015 & 2016 \\
\hline Angka Partisipasi & \multirow{2}{*}{ Per 1000 } & & 73,97 & 78,16 & 75,38 & 76,99 \\
$\begin{array}{l}\text { Pendidikan Anak } \\
\text { Usia Dini (PAUD) }\end{array}$ & & & & & & \\
\hline
\end{tabular}

Sumber: RPJMD Kabupaten Batang 2017-2022 
Gambaran kinerja pendidikan dasar 9 tahun di Kabupaten batang tahun 2012-2016 dapat dilihat dari indikator angka partisipasi, angka pendidikan yang ditamatkan penduduk, angka putus sekolah dan angka kelulusan di table 3 berikut.

Tabel 3. Capaian Indikator Pendidikan Dasar 9 Tahun di Kabupaten Batang 2012-2016

\begin{tabular}{|c|c|c|c|c|c|c|}
\hline \multirow{2}{*}{ Indikator } & \multirow[t]{2}{*}{ Satuan } & \multicolumn{5}{|c|}{ Capaian Kinerja Tahun } \\
\hline & & 2012 & 2013 & 2014 & 2015 & 2016 \\
\hline Angka Partisipasi Kasar (APK) & & & & & & \\
\hline APK SD/sederajat & $\%$ & 102,5 & 102,3 & 106,95 & 105,35 & 104,7 \\
\hline $\begin{array}{l}\text { APK SMP/sederajat } \\
\text { Angka Partisipasi Murni (APM) }\end{array}$ & & 87,89 & 88,51 & 91,32 & 91,66 & 95,36 \\
\hline APK SD/sederajat & $\%$ & 90,26 & 90,42 & 94,27 & 96,40 & 94,04 \\
\hline $\begin{array}{l}\text { APK SMP/sederajat } \\
\text { Angka Partisipasi Sekolah }\end{array}$ & & 66,03 & 70,35 & 74,21 & 74,66 & 80,69 \\
\hline APK SD/sederajat & Per 1000 & 902,6 & 904,2 & 942,7 & 946,0 & 975,1 \\
\hline $\begin{array}{l}\text { APK SMP/sederajat } \\
\text { Angka Pendidikan yang } \\
\text { ditamatkan Penduduk }\end{array}$ & & 660,3 & 703,5 & 742,1 & 746,6 & 760,1 \\
\hline $\mathrm{SD} /$ sederajat & $\%$ & 40,68 & 42,65 & 41,32 & 40,15 & 39,98 \\
\hline $\begin{array}{l}\text { SMP/sederajat } \\
\text { Angka Putus Sekolah }\end{array}$ & & 12,89 & 16,06 & 16,14 & 16,02 & 15,95 \\
\hline $\begin{array}{l}\text { SD/MI } \\
\text { SMP/MTs }\end{array}$ & $\%$ & $\begin{array}{l}0,15 \\
0,66\end{array}$ & $\begin{array}{l}0,17 \\
0,49\end{array}$ & $\begin{array}{l}0,16 \\
0,09\end{array}$ & $\begin{array}{l}0,11 \\
0,38\end{array}$ & $\begin{array}{l}0,07 \\
0,12\end{array}$ \\
\hline $\begin{array}{l}\text { Angka Kelulusan } \\
\text { SD/MI }\end{array}$ & $\%$ & 99,85 & 100 & 96,7 & 98,87 & 99,78 \\
\hline $\begin{array}{l}\text { SMP/MTs } \\
\text { Angka melanjutkan dari SD/MI } \\
\text { ke SMP/MTs }\end{array}$ & $\%$ & $\begin{array}{l}98,87 \\
90,19\end{array}$ & $\begin{array}{l}99,81 \\
92,11\end{array}$ & $\begin{array}{l}96,18 \\
92,85\end{array}$ & $\begin{array}{r}99,9 \\
92,83\end{array}$ & $\begin{array}{l}` 99,89 \\
95,54\end{array}$ \\
\hline $\begin{array}{l}\text { Angka melanjutkan dari } \\
\text { SMP/MTs ke SMA/SMK/MA }\end{array}$ & $\%$ & 54,96 & 75,24 & 74,99 & 72,71 & 74,15 \\
\hline
\end{tabular}

Sumber : RPJMD Kabupaten Batang 2017-2022

Gambaran kinerja pendidikan menengah di Kabupaten Batang tahun 2012-2016 dapat dilihat dari indikator angka partisipasi, angka pendidikan yang ditamatkan, angka putus sekolah dan angka kelulusan sebagaimana tersaji pada tabel 4 berikut: 
Tabel 4. Capaian Indikator Pendidikan Menengah Kabupaten Batang 2012-2016

\begin{tabular}{lcrrrrr}
\hline \multirow{2}{*}{ Indikator } & \multirow{2}{*}{ Satuan } & \multicolumn{5}{c}{ Capaian Kinerja Tahun } \\
\cline { 3 - 7 } & & 2012 & 2013 & \multicolumn{1}{c}{2014} & 2015 & 2016 \\
\hline APK SMA/Sederajat & $\%$ & 37,32 & 42,21 & 50,51 & 62,23 & 67,28 \\
APM SMA/Sederajat & $\%$ & 30,71 & 33,14 & 40,67 & 40,72 & 48,30 \\
Angka Pendidikan yang & & 7,43 & 8,86 & 8,85 & 8,80 & 11,69 \\
ditamatkan Jenjang & $\%$ & & & & & \\
SMA/Sederajat & & & & & & \\
Angka Putus Sekolah & $\%$ & 0,63 & 0,46 & 0,44 & 0,33 & 0,23 \\
Angka Kelulusan & $\%$ & 99,86 & 99,96 & 100 & 99,98 & 92,79 \\
Angka Partisipasi Sekolah & Per 1000 & 307,1 & 331,4 & 406,7 & 407,2 & 483,0
\end{tabular}

Sumber : RPJMD Kabupaten Batang 2017-2022

Gambaran kondisi kinerja sarana dan prasarana baik pendidikan dasar maupun tahun 2012-2016 dapat dilihat pada tabel 5 pendidikan menengah di Kabupaten Batang berikut:

Tabel 5. Capaian Indikator Sarana dan Prasarana Kabupaten Batang 2012-2016

\begin{tabular}{lcccccc}
\hline \multicolumn{1}{c}{ Indikator } & \multirow{2}{*}{ Satuan } & \multicolumn{5}{c}{ Capaian Kinerja Tahun } \\
\cline { 3 - 7 } & & 2012 & 2013 & 2014 & 2015 & 2016 \\
\hline $\begin{array}{l}\text { Rasio Ketersediaan Sekolah } \\
\text { per Penduduk Usia Sekolah } \\
\text { (Pendidikan Dasar) }\end{array}$ & Per 1000 & 60,21 & 60,02 & 43,98 & 64,37 & 64,37 \\
$\begin{array}{l}\text { Rasio Ketersediaan Sekolah } \\
\text { per Penduduk Usia Sekolah } \\
\text { (Pendidikan Menengah) }\end{array}$ & Per 1000 & 9,70 & 10,19 & 12,72 & 13,54 & 13,54 \\
& & & & & & \\
$\begin{array}{l}\text { Fasilitas Pendidikan } \\
\text { Sekolah Pendidikan SD/MI }\end{array}$ & & 99,40 & 99,84 & 96,03 & 96,59 & \\
$\begin{array}{l}\text { Kondisi Bangunan Baik } \\
\text { Sekolah Pendidikan }\end{array}$ & $\%$ & & & & & \\
$\begin{array}{l}\text { SMP/MTs dan } \\
\text { SMA/SMK/MA Kondisi }\end{array}$ & $\%$ & 95,21 & 96,11 & 98,86 & 98,63 & \\
Bangunan Baik & & & & & \\
\hline
\end{tabular}

Sumber: RPJMD Kabupaten Batang 2017-2022

Dalam rangka meningkatkan mutu pelayanan pendidikan dan mengurangi jumlah anak putus sekolah maka ditempuh kebijakan melalui Pembebasan Biaya Pendidikan Dasar Negeri se-Kabupaten Batang yang diselenggarakan oleh pemerintah. Untuk peningkatan dan pemenuhan kebutuhan sarana dan prasarana pendidikan telah dilakukan upaya peningkatan sarana dan prasarana pendidikan dasar SD sejumlah 21 sekolah, SMP sejumlah 9 sekolah, rehabilitasi sedang dan berat bangunan sekolah SD sejumlah 4 sekolah, pembangunan perpustakaan sekolah SD sejumlah 39 sekolah, penambahan ruang kelas SD sejumlah 1 sekolah, SMP sejumlah 4 sekolah, pembangunan laboratorium dan ruang praktikum 4 sekolah, rehabilitasi sedang dan berat ruang kelas 204 ruang, SMP sejumlah 22 sekolah, pembangunan ruang kelas SMP sejumlah 14 ruang.

Berdasarkan tabel 2 terlihat peningkatan capaian Angka Partisipasi anak usia dini (PAUD) tiap tahunnya dari $73,8 \%$ di tahun 2012 meningkat menjadi $73,97 \%$ di tahun 2013 , meningkat kembali pada tahun 2014 menjadi 
$78,16 \%$ kemudian mengalami penurunan pada tahun 2015 menjadi 75,38\% dan tahun 2016 kondisinya meningkat kembali menjadi $76,99 \%$. Artinya penyelenggaraan pendidikan anak usia dini (PAUD) di Kabupaten Batang secara umum sudah berjalan cukup baik karena mengalami peningkatan dari tahun ke tahun.

Berdasarkan hasil penelitian, indikator angka partisipasi kasar (APK) SD/MI/Paket A mengalami fluktuasi dimana capaian tahun 2016 adalah sebesar 104,7, secara umum mengalami peningkatan dari kondisi awal tahun 2012 sebesar 102,05, akan tetapi jika dibandingkan dengan tahun 2014 dan 2015 capaiannya mengalami penurunan dimana pada tahun 2014 sebesar 106,95 dan 2015 sebesar 105,35. Sedangkan pada indikator angka partisipasi kasar (APK) SMP/MTs/Paket B cenderung mengalami peningkatan dari 87,89 pada tahun 2012 menjadi 95,36 pada tahun 2016.

Capaian indikator angka partisipasi murni (APM) SD/MI/Paket A mengalami fluktuasi, pada tahun 2012 capaianya adalah 90,26 meningkat menjadi 90,42 pada tahun 2013, 94,27 pada tahun 2014 dan 96,40 pada tahun 2015, akan tetapi setelah itu capainya sedikit menurun menjadi 94,04 pada tahun 2016. Sedangkan capaian indikator angka partisipasi murni (APM) SMP/MTs/Paket B cenderung terus mengalami peningkatan dari kondisi tahun 2012 sebesar 66,03 menjadi 80,69 pada tahun 2016. Capaian indikator angka partisipasi sekolah jenjang SD/sederajat secara umum mengalami peningkatan dari capaian tahun 2012 adalah sebesar 902,6 menjadi 975,1 pada tahun 2016, begitu juga pada angka partisipasi sekolah jenjang SMP/Sederajat mengalami peningkatan dari capaian tahun 2012 sebesar 660,3 menjadi 760,1 pada tahun 2016.

Capaian indikator angka pendidikan yang ditamatkan penduduk pada jenjang $\mathrm{SD} /$ sederajat berdasarkan hasil penelitian diketahui bahwa selama kurun waktu 2012-2016 mengalami penurunan dari kondisi tahun 2012 sebesar 40,68 menjadi 39,98 di tahun 2016. Sementara itu pada jenjang SMP/sederajat mengalami kondisi yang fluktuatif, jika dilihat dari kondisi tahun 2012 angkanya naik dari sebesar 12,89 menjadi 15,59 di tahun 2016, kan tetapi jika dibandingkan dengan capaian tahun 2013, 2014 dan 2015 angkanya menurun.

Capaian indikator angka putus sekolah pada jenjang SD/MI secara umum cenderung mengalami peningkatan kinerja dimana terjadi penurunan dari angka 0,15 pada tahun 2012 menjadi 0,07 pada akhir periode 2016. Sedangkan capaian angka putus sekolah pada jenjang SMP/MTs secara umum juga cenderung mengalami peningkatan kinerja dimana terjadi penurunan dari angka 0,66 pada tahun 2012 menjadi 0,12 pada tahun 2016 walaupun kondisinya sempat mengalami fluktuasi dimana pada tahun 2012 sempat menyentuh angka 0,09 .

Dalam kurun waktu 2012-2016 capaian kinerja angka kelulusan pada jenjang SD/MI secara umum mengalami penurunan kinerja dari kondisi tahun 2012 sebesar 99,85\% menjadi 99,78\% pada akhir periode 2016, tahun 2013 capaianya sempat menyentuh angka $100 \%$ artinya angka kelulusan perlu ditingkatkan kembali. Sedangkan capaian angka kelulusan pada jenjang SMP/MTs secara umum mengalami peningkatan dari $98,87 \%$ pada tahun 2012 menjadi 99,89 pada tahun 2016.

Selama kurun waktu 2012-2016 capaian indikator angka melanjutkan dari SD/MI ke SMP/MTs cenderung mengalami peningkatan dari kondisi tahun 2012 sebesar $90,19 \%$ menjadi 93,54\% pada akhir periode 2016 begitu juga dengan capaian angka melanjutkan dari SMP/MTs ke SMA/SMK/MA dari kondisi tahun 2012 sebesar $54,96 \%$ menjadi $74,15 \%$ pada tahun 2016. Akan tetapi capaian tertinggi terjadi pada tahun 2013 sebesar 75,24\%.

Berdasarkan tabel 4 dapat disimpulkan bahwa selama kurun waktu 2012-2016 capaian indikator angka partisipasi kasar (APK) SMA/SMK/MA/ Paket C mengalami peningkatan dari kondisi tahun 2012 sebesar 37,32 menjadi 67,28 pada periode 2016 , begitu juga dengan angka partisipasi murni (APM) SMA/SMK/MA/Paket $C$ cenderung terus meningkat dari kondisi tahun 2012 sebesar 30,71 menjadi 48,3 pada periode tahun 2016. Kondisi yang sama juga terjadi pada indikator angka pendidikan yang ditamatkan pada jenjang 
SMA/Sederajat dimana kondisi tahun 2012 capaianya adalah sebesar 7,43 meningkat menjadi 11,69 pada akhir periode 2016. Angka putus sekolah SMA/SMK/MA juga mengalami peningkatan kinerja dimana terjadi penurunan dari angka 0,63 pada tahun 2012 turun menjadi 0,23 pada periode 2016. Kemudian Angka Partisipasi Sekolah Pendidikan Menengah juga mengalami trend peningkatan dari kondisi tahun 2012 sebesar 307,1 menjadi 483,00 pada periode 2016. Sedangkan Angka kelulusan SMA/SMK/MA terjadi penurunan kinerja dari tahun 2012 sebesar 99,86\%, kemudian sempat mencapai $100 \%$ pada tahun 2013 akan tetapi menurun kembali cukup signifikan pada tahun 2016 menjadi 92,79\%. Artinya angka kelulusan pada jenjang SMA/SMK/MA ini perlu untuk tingkatkan kembali.

Berdasarkan tabel 5 dapat disimpulkan bahwa capaian Rasio Ketersediaan Sekolah per Penduduk pada jenjang pendidikan dasar cenderung mengalami peningkatan dari tahun 2012 sebesar 60,21 menjadi 64,37 pada tahun 2016 begitu juga dengan Rasio Ketersediaan Sekolah Per Penduduk pada jenjang pendidikan menengah cenderung mengalami peningkatan dari tahun 2012 sebesar 11,64 menjadi 13,54 pada tahun 2016. Sementara itu capaian indikator Sekolah Pendidikan SD/MI Kondisi Bangunan Baik mengalami fluktuasi dan cenderung menurun dari tahun 2012 sebesar 99,4 menjadi 95,54 pada tahun 2016,begitu juga Sekolah Pendidikan SMP/MTs dan SMA/SMK/MA Kondisi Bangunan Baik cenderung mengalami penurunan dari tahun 2012 sebesar 95,21 menjadi 94,11 pada tahun 2016.

\section{SIMPULAN}

Pencapaian hasil pembangunan dan peningkatan kualitas infrastruktur ekonomi sosial di Kabupaten Batang menjadi kewenangan dari Dinas Pekerjaan Umum dan Penataan Ruang Kabupaten Batang. Hasil pembangunan dan peningkatan kualitas infrastruktur ekonomi sosial di Kabupaten Batang pada tahun 2018 adalah sebesar 75,77\% atau pencapaiannya cukup berhasil/cukup baik.
Capaian pada indikator pendidikan jenjang PAUD mengalami peningkatan dari tahun 2012 sampai 2016 sehingga dapat dikategorikan baik. Pada jenjang sekolah dasar 9 tahun mengalami fluktuasi pada tiap indikator. Capaian pada jenjang SMA/SMK pada tiap indikator mengalami fluktuasi, sementara angka kelulusan pada jenjang SMA/SMK/MA.

\section{DAFTAR PUSTAKA}

Familoni, K.A. (2004). The Role Of Economic And Social Infrastructure In Economic Development: A Global View

Hidayat, Sutanto Dan Mulyadi, Lalu. (2018). Kebijakan Pembangunan Infrastruktur Fisik Belajar Dari Analisis Dampak Sosial Ekonomi Pembangunan Jembatan Suramadu. Jurnal Karya Dosen ITN Malang, Hlm:1-14

LKJIP Dinas Pekerjaan Umum Dan Penataan Ruang Kabupaten Batang, (2018)

Mankiw, N. Gregory. (2003). Pengantar Ekonomi. Edisi Kedua. Jakarta: Erlangga.

Munir. (2002). Perencanaan Pembangunan Daerah Dalam Perspektif Otonomi. NTB: Bappeda

Onisimus, Amtu. (2010). Manajemen Pendidikan di Era Otonomi Daerah (Konsep, Strategi dan Implementasi), Bandung: Alfabeta.

Posumah, Ferdy. (2015). Pengaruh Pembangunan Infrastruktur Terhadap Investasi Di Kabupaten Minahasa Tenggara. Jurnal Berkala Ilmiah Efisiensi Volume 15 No. 02, Hlm:1-15

Purwansyah, Fadly Elwa. (2013). Pengaruh Pembangunan Infrastruktur Terhadap Pengembangan Sektor Pertanian Di Kabupaten Muaro Jambi. Jurnal Perspektif Pembiayaan Dan Pembangunan Daerah Vol. 1 No. 1, Juli, Hlm: 29-34

Rencana Pembangunan Jangka Menengah Kabupaten Batang 2017-2022 
Republik Indonesi. (2003). Undang Undang No 20 Tahun 2003 tentang Sistem Pendidikan Nasional

Sallis, Edward. (2012). Total Quality Management ni Education; Manajemen Mutu Pendidikan. Yogyakarta: IRCiSoD 